\title{
Quality characterization of Niger seed oil (Guizotia Abyssinica Cass.) produced in Amhara Regional State, Ethiopia
}

\author{
Dimberu G. Atinafu ${ }^{1 *}$, Shamshad K. B. ${ }^{2}$ and Solomon Libsu ${ }^{2}$ \\ ${ }^{1}$ Department of Chemistry, College of Natural and Computational Sciences, Wolkite University, Wolkite, Ethiopia. \\ ${ }^{2}$ Department of Chemistry, Faculty of Natural Science, Bahir Dar University, Bahir Dar, Ethiopia.
}

Received 1 October, 2014; Accepted 12 January, 2015

\begin{abstract}
In the present investigation, an attempt has been made to find out cholesterol and total free fatty acid content in Niger seed oil which is the most available edible oil in Ethiopia. Acid value, peroxide value, saponification value and cholesterol content were determined. The analysis performed using Liebermann-Burchard method revealed no level of cholesterol content. Unlike the peroxide value, acid value and saponification value of Niger seed oil show high values in comparison with the maximum permissibility level of Codex Standard for Named Vegetable Oils (CODEX STAN210-1999). In conclusion, this study could be a guide line, to understand the quality of Niger seed oil in Amhara Regional State, Ethiopia. Therefore, companies producing and marketing Niger seed oil are enjoined to inform the public by labeling their products as "cholesterol free".
\end{abstract}

Key words: Niger seed oil, cholesterol and free fatty acid.

\section{INTRODUCTION}

Niger is an oilseed (Neug), which is a new source of vegetable oils; a crop that is produced from Guizotia Abyssinica. It is found mostly in the northern and central highlands at elevations between 1,800 and 2,500 m. Niger seed is the most important oil crop in Ethiopia and a minor crop in India but it is not involved in the worldwide oilseed trade. It provides 50 to $60 \%$ of Ethiopia's indigenous edible oil but only $2 \%$ of India's total oilseed production (Ramadan and Mörsel, 2002). It represents also a minor oilseed crop in some other African countries. Besides cookery, Niger seed oil can be used in the manufacture of soap, paints, or as a lubricant or illuminant. The protein-rich meal which remains after oil extraction is used as a feed, manure or fuel. Regarding the fatty acid profile, Niger seed oil resembles that of safflower and sunflower with its high content of linoleic acid (C18:2n-6) which may be up to $85 \%$ depending on the origin (Ramadan and Mörsel, 2002).

Ethiopian oilseeds and pulses are known for their flavor and nutritional value as they are mostly produced organically. For instance, the Ethiopian white sesame seed is used as a reference for grading in international markets(http://www.ethiopianexporters.com/products.html ). Ethiopia's major oilseed and pulse exports include sesame seeds, Niger seeds, linseeds, sunflower seeds, groundnuts, rapeseeds, castor oil seeds, pumpkin seeds,

${ }^{*}$ Corresponding author. E-mail: chemdimberu2009@yahoo.com. Tel: +251-(0)9-10-12-14-72.

Author(s) agree that this article remains permanently open access under the terms of the Creative Commons Attribution License 4.0 International License 
Table 1. Acid value, peroxide value, saponification value and cholesterol content of Niger seed oil sample.

\begin{tabular}{lcc}
\hline Parameter & Codex standard & Experimental value \\
\hline Acid value $(\mathrm{mg} \mathrm{KOH} / \mathrm{g})$ & 0.6 & $8.69 \pm 0.39$ \\
Peroxide value (meq.peroxide/kg) & 10 & $3.80 \pm 0.28$ \\
Saponification value $(\mathrm{mg} \mathrm{KOH} / \mathrm{g})$ & $188-192$ & $162.76 \pm 0.69$ \\
Cholesterol $(\mathrm{mg} / \mathrm{l})$ & ${ }^{*} \mathrm{ND}$ & ${ }^{*} \mathrm{ND}$ \\
\hline${ }^{*} \mathrm{ND}$ Not detected & &
\end{tabular}

haricot beans, pea-beans, horse beans and chick peasy.

Almost every adult at present times develops some degree of atherosclerosis, commonly known as "hardening of the arteries". Atherosclerosis leads to strokes, heart attacks and other serious health problems. High cholesterol, smoking and high blood pressure are the principal risk factors linked to heart disease.

The word "cholesterol" may quickly be associated with chronic heart disease and other heart problems. However cholesterol also has essential functions in the body such as providing essential components of membrane and serving as a precursor of bile acids, steroid hormones and vitamin D. Consuming cholesterol in our diet increases the level of Low Density Lipoproteins (LDLs). There are different varieties of vegetable oil brands in our markets and all of them claim to be cholesterol free. Due to increasing awareness on the health implications of high cholesterol in the diets, most people now prefer to purchase cholesterol free vegetable oils (Attarde et al., 2010).

One of the other major problem in fats and oil is the development of rancidity (oxidative) and deterioration of its quality due to multiple environmental and storage conditions. The overall effect of oxidation appears in unnecessary economic loss. Oxidation is said to be offflavor, quality, which results from reaction of atmospheric oxygen. The oxidized oils not only deteriorate the taste of foods to which they are added but are considered to create many health problems, that is, diarrhea, poor rate of growth etc. Therefore, the quality of oils is measured by determining selected quality parameters such as peroxide value, free fatty acid and color (Javid et al., 2003).

Normally, fatty acids are found in the triglyceride form; however, during processing the fatty acids may get hydrolyzed (reacts with water) into the free fatty acid. The presence of free fatty acids (FFAs) in oil is an indication of insufficient processing, lipase activity, or other hydrolytic actions (Gaye, 2009). Therefore, the present study was carried out to estimate the extent of rancidity of Niger seed oil under room temperature.

\section{MATERIALS AND METHODS}

The non-branded Niger seed oil used for the study was bought from
Bahir Dar small scale oil factory. Acid, peroxide, and saponification values were determined by standard methods (AOCS, 2003). Cholesterol content was estimated using Liebermann-Burchard reagent (Attarde et al., 2010).

\section{RESULTS AND DISCUSSION}

\section{Acid value}

Acid value was determined to obtain Niger seed oil total free fatty acids that are used in this study. In this study, acid value obtained was $8.69 \pm 0.39 \mathrm{mg} \mathrm{KOH} / \mathrm{g}$ (Table 1). Its value is much higher than the Codex Standard for Named Vegetable Oils (CODEX-STAN210-1999) (0.6 mg $\mathrm{KOH} / \mathrm{g}$ ). This hydrolysis is probably caused by a variety of agents presence, moisture in the oil, elevated temperature (above room temperature) and most important of all, lipases (enzyme) coming from the source or contaminating microorganisms. This observation supports previous study that unrefined vegetable oils had higher acid value than recommended value (Rajko et al., 2010), which indicate high free fatty acids and leads to a tendency to become rancid that is off-flavor (Tamzid et al., 2007). Probably, during processing the fatty acids may react with water and get hydrolyzed into the free fatty acids. In addition, Niger seed oil is processed other than chemical refining methods (neutralization), which lower the free fatty acid content (Cmolik and Pokorny, 2000). Long storage of the oil seeds before or after processing may also have been responsible. Kalua et al. (2008) discussed that there were changes in oil quality during cold temperature storage of the fruit. This high content of free fatty acid levels has high probability for decreasing the ability of liver to store sugars (Gur and Harwood, 1991.

\section{Peroxide value}

Peroxide value is the chemical parameter which is frequently used. It is applied in Niger seed oil sample for the purpose of estimating the Niger seed oil oxidation towards unsaturation apart from getting estimations on the stability of Niger seed oil at low temperature. On top of that, peroxide value is closely related to certain samples' unsaturation; the more unsaturated a sample is, the higher the probability to have high peroxide value. 
According to Codex Standard for Named Vegetable Oils (CODEX-STAN210-1999), the peroxide value for Niger seed oil is 10 meq.peroxide/kg. The high values of peroxide obtained could indicate the onset of primary oxidation due to lipid degrading enzymes like peroxidase and lipoxygenase (Onyeka et al., 2005).

In this study, peroxide value obtained was $3.80 \pm 0.28$ meq.peroxide/kg (Table 1). Its value is lower than the codex standard permissibility level, which indicates that Niger seed oil may contain preservatives either synthetic or natural hence, reduces the high peroxide value over time. In addition, Niger seed oil may have low content of unsaturation, which are responsible for oxidation and leads to rancidity or off-flavor and present results are in line with the reported literature (Chabiri et al., 2009; Dimberu and Belete, 2011).

\section{Saponification value}

Saponification value is determined to obtain Niger seed oil chain length that is used in this study. According to Codex Standard for Named Vegetable Oils (CODEXSTAN210-1999), saponification value of Niger seed oil is in the range of $188-192 \mathrm{mg} \mathrm{KOH} / \mathrm{g}$ with the average value of $190 \mathrm{mg} \mathrm{KOH} / \mathrm{g}$. In this study, saponification value obtained is $162.76 \pm 0.69 \mathrm{mg} \mathrm{KOH} / \mathrm{g}$ (Table 1 ), which suggest that it contains high molecular weight long chain fatty acids hence are unsuitable for soap making and also unsuitable for human nutrition (Akinhanmi and Atasie, 2008). Lower saponification value indicates high proportion of longer fatty acids since saponification value is inversely proportional to the average molecular weight or chain length of the fatty acids (Muhammad et al., 2011). Therefore, the shorter the average chain length $\left(\mathrm{C}_{4}-\mathrm{C}_{12}\right)$ the higher the saponification number (Tamzid et al., 2007). The value obtained for Niger seed oil during this study show that it contains high amounts of long chain fatty acids $\left(<\mathrm{C}_{12}\right)$. Geographical factor most probably owing to influence the Niger seed oil product where different plantation area gives different products (Khazainah et al., 2011).

\section{Cholesterol content}

In this study cholesterol was not detected which is in line with the recommended value. It suggests that Niger seed may have high content of phytosterols, which has the ability to decrease cholesterol levels (Mortuza, 2006; Dept Health and Human Services, Food and Drug Administration, 2000).

Phytosterols compete with cholesterol absorption and uptake in the small intestine thereby reducing the supply of cholesterol in the blood stream (Muhammet and Samija, 2006). Since high blood total cholesterol and lowdensity lipoprotein (LDL) cholesterol levels are the main risk factors for coronary heart disease (CHD) and other diseases related to atherosclerosis, reducing cholesterol levels reduces the risk of CHD. Phytosterols have no effect on the levels of triacylglycerol or HDL cholesterol. Plant sterols differ from cholesterol in the presence of a methyl or ethyl group in the side chain. This difference enables plant sterols and stanols to be absorbed minimally or not at all by the intestines. Most of the ingested plant sterols pass through the gut and are excreted. Oils containing high level of polyunsaturated fatty acid are also found to inhibit the activity of hydroxymethylglutaryl-coenzymeA-reductase (HMG-CoAreductase) which is the regulatory enzyme in cholesterol biosynthesis (Carl et al., 2009; Seddigheh et al., 2009; Ejikeme et al., 2010).

Finding from this study opposed previous work that cholesterol is present in vegetable oils, although in small proportion (Okpuzor et al., 2009; Syed et al., 2003).

\section{Conclusions}

The results obtained from the study showed that unlike acid value, peroxide value and saponification value of Niger seed oil sample investigated were within the standard which is recommended by Codex Standard for Named Vegetable Oils (CODEX-STAN210-1999). In addition, cholesterol content of Niger seed oil was nil therefore, it is reasonable to conclude that Niger seed oil sample investigated was adequate. The results also indicate the suitability of the oil samples for domestic or industrial applications as well as export trade.

\section{Conflict of Interests}

The author(s) have not declared any conflict of interests.

\section{ACKNOWLEDGEMENTS}

We the authors wish to express our profound gratitude to the Department of Chemistry, Bahir Dar University, Ethiopia, Yewub Geremew Atinafu and Rahel Melak Mehari.

\section{REFERENCES}

Akinhanmi TF, Atasie VN (2008). Chemical composition and physicochemical properties of cashew nut (Anacardium occidentale) Oil and Cashew nut Shell Liquid. J. Agric. Food Environ. Sci. 2: 1-10.

AOCS (2003). Official Method Cd 8-53. American Oil Chemists Society, Champaign, IL. Accessed on www.bioriginal.com.

Attarde D, Pawar J, Chaudhari B, Pal S (2010). Estimation of sterols content in edible oil and ghee samples. Int. J. Pharm. Sci. Rev. Res. 5:135-137.

Carl JL, Richard VM, Mandeep RM, Hector OV (2009). Omega-3 Polyunsaturated Fatty Acids and Cardiovascular Diseases. J. Am. Coll. Cardiol. 54:585-594.

Chabiri SA, Hati SS, Dimari GA, Ogugbuaja VO (2009). Comparative 
quality assessment of branded and unbranded edible vegetable oils in Nigeria. Pac. J. Sci. Technol. 10:927-934.

Cmolik J, Pokorny J (2000). Physical refining of edible oils. Eur. J. Lipid Sci. Technol. 102:472-486.

Dept Health and Human Services, Food and Drug Administration (2000) Health Claim: Plant sterol/stanol esters and the risk of coronary heart disease. 21CFR101.83. Accessed on www.cfsan.fda.gov/ Ird/cf10183.html.

Dimberu GA, Belete B (2011). Estimation of total free fatty acid and cholesterol content in some commercial edible oils in Ethiopia, Bahir DAR. J. Cereals Oilseeds. 2: 71-76.

Ejikeme PM, Obasi LN, Egbuonu AC (2010). Physico-chemical and toxicological studies on Afzelia africana seed and oil. Afr. J. Biotechnol. 9:1959-1963.

Gaye Y (2009). Effect of storage time on olive oil quality. M.Sc. Thesis, İzmir Institute of Technology, Turkey.

Gur MI, Harwood JL (1991). Lipid Biochemistry: An introduction. London: Chapman and Hall, p. 406.

http://www.ethiopianexporters.com/products.html. Accessed on 13/6/2011.

Javid U, Hamayoun M, Taufiq A, Ayub M, Zafarullah M (2003). Effect of light, natural and synthetic antioxidants on stability of edible oil and fats. Asian J. Plant Sci. 2:1192-1194.

Kalua CM, Bedwood DR, Bishop AG, Pienzler PD (2008). Changes in virgin oil quality during low temperature fruit storage. J. Agric. Food Chem. 56:2415-2422.

Khazainah K, Mushaireen M, Kamaruzaman J, Rahman A, Zetty M, Zaini Md, Azlina S (2011). Lowering of palm oil cloud point by enzymatic acidolysis. World Appl. Sci. J. 12:28-31.

Mortuza MG (2006). Tocopherol and sterol content of some rapeseed/mustard cultivars developed in Bangladesh. Pak. J. Biol. Sci. 9:1812-1816.
Muhammad N, Bamishaiye E, Bamishaiye O, Usman L, Salawu M, Nafiu M, Oloyede O (2011). Physicochemical properties and fatty acid composition of cyperus esculentus (Tiger Nut) Tuber Oil. Biores. Bull. 5:51-54.

Muhammet KG, Samija A (2006). Sterols and the phytosterol content in oilseed rape (Brassica napus L.). J. Cell Mol. Biol. 5:71-79.

Okpuzor J, Okochi VI, Ogbunugafor HA, Ogbonnia S, Fagbayi T, Obidiegwu C (2009). Estimation of cholesterol level in different brands of vegetable oils. Pak. J. Nutr. 8:57-62.

Onyeka EU, Onugbu NI, Onuoha NU, Ochonogor F (2005). Effect of extraction pretreatment on the composition and characteristics of seed and pulp oil of African black pear (Dacryodes edulis). Niger. Food J. 23:13-20.

Rajko V, Sergeja V, Helena A (2010). Biochemical parameters and oxidative resistance to thermal treatment of refined and unrefined vegetable edible oils. Czech J. Food Sci. 28: 376-384.

Ramadan MF, Mörsel JT (2002). Proximate neutral lipid composition of niger (Guizotia abyssinica Cass.) seed. Czech J. Food Sci. 20:98-104. Seddigheh A, Bahar N, Nizal S, Sahar P, Salbali S, Ahmad E, Leila A (2009). Evaluation of fatty acid content of some Iranian fast foods with emphasis on trans fatty acids. Asia Pac. J. Clin. Nutr. 18: 187192.

Syed MS, Imran H, Syed DAG (2003). Estimation of sterols in edible fats and oils. Pak. J. Nutr. 2:178-181.

Tamzid HM, Alam MT, A-U-Islam M (2007). Physico-chemical and nutritional studies of terminalia belerica roxb. Seeed oil and seed kernel. J. Bio-Sci. 15:117-126. 